\section{Could abatacept directly target expanded plasmablasts in IgG4-related disease?}

Yamamoto et $a l^{1}$ recently reported the case of a patient with long-standing and relapsing IgG4-related disease (IgG4-RD), who developed secondary resistance to rituximab treatment but subsequently improved under abatacept infusions. This interesting observation drives important questions, regarding both IgG4-RD pathophysiology and abatacept mechanisms of action.

IgG4-RD is a systemic disease of unknown cause, affecting primarily middle-aged men, characterised by swelling of one or several organs (mainly pancreas, salivary and lachrymal glands, lymphadenopathy, retroperitoneal organs) with infiltration of
IgG4-positive plasma cells and fibrosis of involved organs, and high serum IgG4 levels in half of the patients. ${ }^{2}{ }^{3}$ Several diagnostic or classification systems have been proposed. ${ }^{45}$

Its pathophysiology is still ill-defined. ${ }^{6}$ IgG4-secreting plasmablasts are central players in the disease: they are the main infiltrating cells in affected organs, they are expanded in the circulation, are oligoclonal ${ }^{7}$ and may serve as a biomarker to guide therapy. ${ }^{8}$ The efficacy of rituximab in IgG4-RD further suggests the major role of $\mathrm{B}$ cells as precursors of these expanded plasmablasts. ${ }^{9} 10$ It has been suggested that a shift towards Th2 immune response promotes the initiation of the disease, ${ }^{11}$ and that overexpression of IL-21 by Tfh cells leads to the formation of ectopic germinal centres in the target organs and increased IgG4 production. ${ }^{12}$ B-cell/plasmablast and T-cell relative contributions in the pathophysiology of IgG4-RD are
Figure 1 Abatacept is able to bind CD19 ${ }^{+}$B cells and CD38 $8^{\text {high }}$

plasmablasts. Flow cytometry analysis was performed on peripheral blood mononuclear cells from a normal donor, stained with Alexafluor700-conjugated anti-CD19, Krome orange-conjugated anti-CD3, Phycoerythrin Cyanin 5.5-conjugated anti-CD38 antibodies and biotinylated abatacept revealed by fluorescein isothiocyanate (FITC)-conjugated streptavidine. (A) Gating strategy for CD3 ${ }^{-}$CD19 ${ }^{+}$B cells, CD3 ${ }^{+}$CD19- $9^{-}$ cells and $\mathrm{CD} 19^{+} \mathrm{CD} 38^{\text {high }}$ plasmablasts. (B) Histograms are showing percentage of gated biotinylated abataceptpositive cells in $\mathrm{CD}_{19} \mathrm{CD}^{-} \mathrm{B}$ cells (grey line) on the left part and CD $19^{+}$CD38 $8^{\text {high }}$ plasmablasts (grey line) on the right part, compared with CD19 ${ }^{-} \mathrm{CD}^{+}{ }^{+}$T cells (black line on both left and right panels). INT, integral; FS, forward scatter; SS, side scatter.

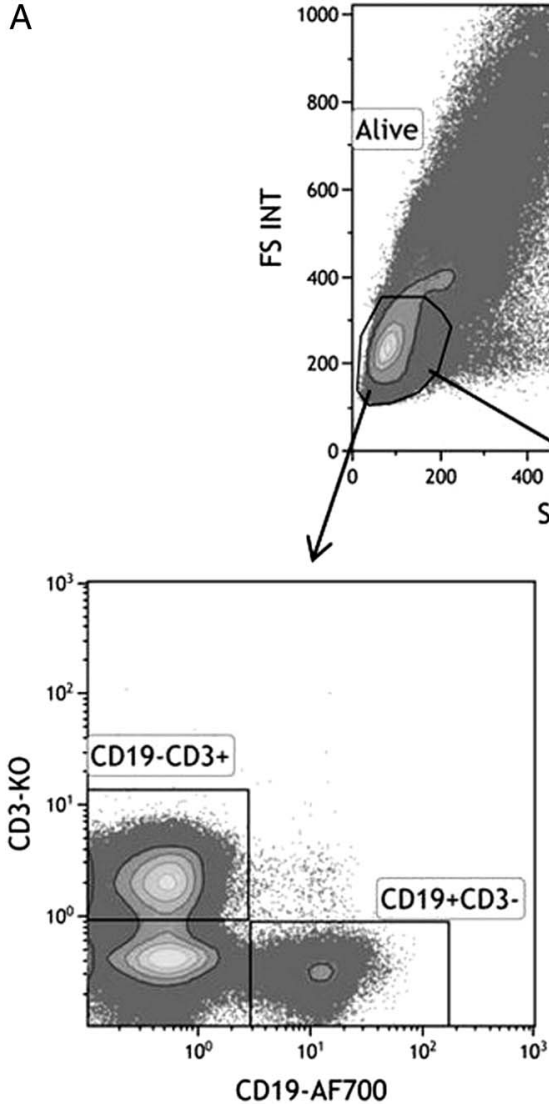

B
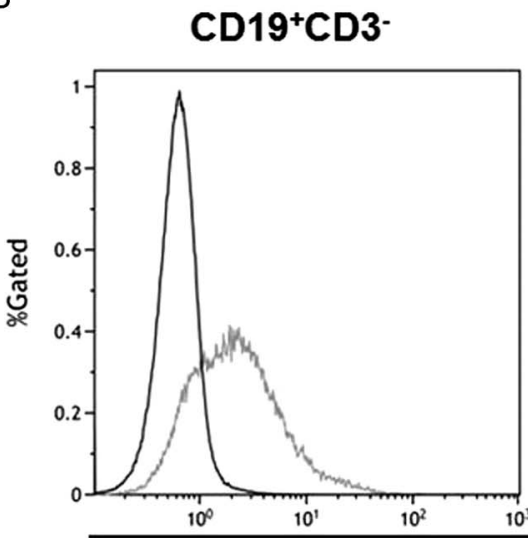
difficult to decipher, as illustrated by the disappearance of a recently described oligoclonal CD4+ cytotoxic T-cell subpopulation after B-cell depletion using rituximab. ${ }^{13}$

Abatacept is a fusion protein combining the extracellular domain of CTLA4 with an IgG1 Fc fragment, labelled for the treatment of rheumatoid arthritis (RA). Abatacept has greater binding affinity for CD80/CD86, expressed chiefly on the surface of monocytes, dendritic cells and B cells, than CD28 on the surface of T cells. It is suspected that abatacept acts primarily by impairing CD28-mediated activation of T cells. ${ }^{14}$ Therefore, Yamamoto et al suggest that the efficacy of abatacept in their patient is mainly explained by an inhibition of Tfh and subsequent disruption of the formation of ectopic germinal centres.

However, we would like to discuss an alternate explanation to the potential efficacy of abatacept in IgG4-RD: abatacept may also act directly on those expanded plasmablasts observed in the disease. Several observations suggest that abatacept may indeed have a direct effect on CD80/CD86-expressing cells to which it binds. In RA, abatacept increases blood monocyte counts by decreasing their vascular adherence and migratory capacity ${ }^{15}$ and modulates B-cell intra-cellular signalling pathways. ${ }^{16}$ Its clinical efficacy in RA is associated with higher pretreatment circulating B-cell levels, which subsequently decrease in responder patients. ${ }^{17}$ The proportion of circulating CD80- and CD86-positive B cells is drastically increased in patients with IgG4-RD, paralleling the expanded circulating plasmablast population. ${ }^{18}$ In figure 1, we show by fluorescence-activated cell sorting (FACS) analysis that $\mathrm{CD} 19^{+} \mathrm{B}$ cells and $\mathrm{CD} 19^{+} \mathrm{CD} 38^{\text {high }}$ plasmablasts are able to bind abatacept. Considering that IgG4-RD plasmablasts express high levels of CD80 and CD86 we may hypothesise that, in this patient with refractory IgG4-RD, abatacept also bound on the surface of those expanded plasmablasts and led to their inhibition or even depletion through Fc-mediated mechanisms (complement- or celldependent cytotoxicity). This hypothesis should be confirmed by future studies, which may reveal a new important mechanism of action of abatacept.

Guillermo Carvajal Alegria, ${ }^{1,2}$ Pierre Pochard, ${ }^{1}$ Jacques-Olivier Pers, ${ }^{1}$ Divi Cornec ${ }^{1,2}$

${ }^{1}$ INSERM ESPRI, ERI29/EA2216, European University of Brittany, Brest, France ${ }^{2}$ Service de Rhumatologie, CHRU Brest, Brest, France

Correspondence to Dr Divi Cornec, Service de Rhumatologie, CHRU Brest, Hôpital de la Cavale Blanche, BP 824, Brest cedex F 29609, France; divi.cornec@ chu-brest.fr

Competing interests None declared.

Provenance and peer review Not commissioned; internally peer reviewed.

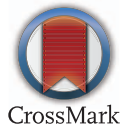

To cite Carvajal Alegria G, Pochard P, Pers J-0, et al. Ann Rheum Dis 2016;75: e73.
Received 22 August 2016

Accepted 23 August 2016

Published Online First 13 September 2016

\section{Linked}

http://dx.doi.org/10.1136/annrheumdis-2016-210403

Ann Rheum Dis 2016;75:e73. doi:10.1136/annrheumdis-2016-210400

\section{REFERENCES}

1 Yamamoto M, Takahashi H, Takano K, et al. Efficacy of abatacept for IgG4-related disease over 8 months. Ann Rheum Dis 2016;75:1576-8.

2 Brito-Zerón $\mathrm{P}$, Ramos-Casals $\mathrm{M}$, Bosch $\mathrm{X}$, et al. The clinical spectrum of IgG4-related disease. Autoimmun Rev 2014;13:1203-10.

3 Wallace ZS, Deshpande V, Mattoo $\mathrm{H}$, et al. IgG4-related disease: clinical and laboratory features in one hundred twenty-five patients. Arthritis Rheumatol 2015;67:2466-75.

4 Stone JH, Brito-Zerón P, Bosch X, et al. Diagnostic approach to the complexity of IgG4-related disease. Mayo Clin Proc 2015;90:927-39.

5 Okazaki K, Tomiyama T, Mitsuyama T, et al. Diagnosis and classification of autoimmune pancreatitis. Autoimmun Rev 2014;13:451-8.

6 Islam AD, Selmi C, Datta-Mitra A, et al. The changing faces of IgG4-related disease: clinical manifestations and pathogenesis. Autoimmun Rev 2015;14:914-22.

7 Mattoo H, Mahajan VS, Della-Torre E, et al. De novo oligoclonal expansions of circulating plasmablasts in active and relapsing IgG4-related disease. J Allergy Clin Immunol 2014;134:679-87.

8 Wallace ZS, Mattoo $\mathrm{H}$, Carruthers $\mathrm{M}$, et al. Plasmablasts as a biomarker for IgG4-related disease, independent of serum IgG4 concentrations. Ann Rheum Dis 2015;74:190-5.

9 Carruthers MN, Topazian MD, Khosroshahi A, et al. Rituximab for IgG4-related disease: a prospective, open-label trial. Ann Rheum Dis 2015:74:1171-7.

10 Della-Torre E, Feeney E, Deshpande V, et al. B-cell depletion attenuates serological biomarkers of fibrosis and myofibroblast activation in lgG4-related disease. Ann Rheum Dis 2015;74:2236-43.

11 Akiyama M, Suzuki K, Yamaoka K, et al. Number of circulating follicular helper $2 \mathrm{~T}$ cells correlates with lgG4 and interleukin-4 levels and plasmablast numbers in IgG4-related disease. Arthritis Rheumatol 2015;67:2476-81.

12 Moriyama M, Tanaka A, Maehara T, et al. T helper subsets in Sjögren's syndrome and IgG4-related dacryoadenitis and sialoadenitis: a critical review. J Autoimmun 2014;51:81-8.

13 Mattoo H, Mahajan VS, Maehara T, et al. Clonal expansion of CD4(+) cytotoxic T lymphocytes in patients with IgG4-related disease. J Allergy Clin Immunol 2016;138:825-38.

14 Cutolo M, Nadler SG. Advances in CTLA-4-Ig-mediated modulation of inflammatory cell and immune response activation in rheumatoid arthritis. Autoimmun Rev 2013;12:758-67

15 Bonelli M, Ferner E, Göschl L, et al. Abatacept (CTLA-4IG) treatment reduces the migratory capacity of monocytes in patients with rheumatoid arthritis. Arthritis Rheum 2013;65:599-607.

16 Iwata S, Nakayamada S, Fukuyo S, et al. Activation of Syk in peripheral blood B cells in patients with rheumatoid arthritis: a potential target for abatacept therapy. Arthritis Rheumatol 2015;67:63-73.

17 Gazeau P, Devauchelle-Pensec V, Pochard P, et al. Abatacept efficacy in rheumatoid arthritis is dependent upon baseline blood B-cell levels. Rheumatology (Oxford) 2016;55:1138-40.

18 Lin W, Jin L, Chen $\mathrm{H}$, et al. B cell subsets and dysfunction of regulatory B cells in lgG4-related diseases and primary Sjögren's syndrome: the similarities and differences. Arthritis Res Ther 2014;16:R118. 